\title{
A „SZEGED REGIONÁLIS HULLADÉKGAZDÁLKODÁSI PROGRAM" ISPA PROJEKT MEGVALÓSULT BERUHÁZÁSAINAK ÜZEMELTETÉSI TAPASZTALATAI
}

\author{
Szabó Ferenc ${ }^{1}$ - Keczer Gabriella ${ }^{2}$ \\ 'óraadó, környezetvédelmi szakmérnök, Szegedi Tudományegyetem Mérnöki Kar \\ ${ }^{2}$ föiskolai adjunktus, Szegedi Tudományegyetem Mérnöki Kar
}

\begin{abstract}
Summary
In my paper I analyze the operational experiences of the „Szeged Regional Waste Management Program" ISPA project. On the basis of the case study we can conclude, that the outcomes of engineering, PR and procurement projects turn to be trouble-free, but facilities implemented in the frame of constructional projects suffer several difficulties when operated. Thus, the operational problems are not necessary, but are the consequences of the tender procedures. The main reasons are the lack of professionalism, the consciously underestimated implementation costs on the side of the contractor, and the lack of cooperation between the main actors of the project.
\end{abstract}

\section{BEVEZETÉS}

A projekt tervezés és előkészités, továbbá a közbeszerzési eljárás lebonyolitását és a szerzőkötést követően kezdetét veszi a koncentrált erőforrás-lekötést és felhasználást igénylő tényleges megvalósítás, ahol a tervezés (kiviteli tervek és a megvalósult állapotrögzítö tervek), az építés-szerelés és próbaüzem a szakmai sajátosságoknak megfelelö müszakigazdasági törvényszerüségek szerint lezajlanak. A létesítmény megvalósítás folyamatának ez a szakasza közvetlenül eredményezi magát a fizikailag is kész - üzemszerü mükődésre, vagy használatra alkalmas - termelö- vagy szolgáltató létesítményt. (Görög, 2001)

A „Szeged Regionális Hulladékgazdálkodási Programja” elnevezésü Kohéziós Alap (korábban ISPA) projekt vizsgálata alapján kívánom bemutatni a hazai európai uniós környezetvédelmi infrastruktúra fejlesztési projektek keretében megvalósult beruházások üzemeltetési tapasztalatait és az ủzemeltetés során jelentkező tipikus problémákat.

Ezeknek a vizsgálatoknak eredményekét vonhatók le olyan általános következtetések és tanulságok, amelyeket más hasonló hazai projektek megvalósításának tapasztalatai is teljes mértékben alátámasztanak. A mérnök, a PR és a beszerzési tender zökkenömentes lebonyolítása és a megkötött szerződések teljesítése ráirányíthatja a figyelmet arra, hogy az uniós és hazai közbeszerzési eljárások súlyos müködési zavarai nem szükségszerüek, és szinte kizárólag csak az építési beruházások esetében jelentkeznek.

\section{KUTATÁSI EREDMÉNYEK}

A közbeszerzési eljárás lebonyolítása az EU által jóváhagyott, többször módosított közbeszerzési terv szerint történt. A közbeszerzési terv végső változata szerint az alábbi tenderek valósultak meg, melyeknek eddigi üzemeltetési tapasztalatait tekintettem át időrendi sorrendben:

$>$ Mérnök (Operatív irányítás, müszaki ellenőrzés, koordináció)

$>$ PR (Kommunikációs feladatok)

1.sz. Építési (Infrastruktúra: utak, térburkolatok, nyomvonalas létesítmények) 
2. sz. Építési (Depónia korszerüsítés: szigetelés, biogáz hasznosítás, szennyvíztisztító, komposztáló és egyéb létesitmények)

$>$ Beszerzési (Szállítójármũvek, munkagépek, egyes technológiai berendezések és eszközök, hulladékgyüjtő konténerek)

$>$ 3. sz. Építési (Hulladékudvarok, gyưjtőszigetek építőmesteri munkái)

\section{Az egyes tenderek megvalósítása és az üzemeltetés tapasztalatai}

A projekt jelenlegi állása szerint (2008. november 01.) a különböző tenderek végrehajtása során megvalósult létesítmények és beszerzett eszközök üzemeltetése következöképpen alakult:

\section{A Mérnök Tender (Mérnök szerződés) és PR tender (PR szerződés):}

A mérnöki szervezet feladata a projekt legszélesebb értelemben vett szakmai irányítása, koordinálása és a müszaki ellenőrzés, mig a PR szerződés célja és tárgya a projekt célok megismertetése, népszerüsitése valamint a környezet- és természetvédelem ügyének előmozdítása, a környezettudatosság erōsítése, a lakosság együttmüködési készségének kialakítása, fejlesztése.

Jellegükből adódóan e tenderek estében üzemeltetési tapasztalatokról nem beszélhetünk, hiszen ezek a szerzỏdések a projekt bonyolításához szükséges speciális szolgáltatásokat biztositottak és a projekt befejeződésével megszüntek.

\section{1.sz. Építési tender - 1.sz. Építés szerződés:}

Tárgya a szegedi regionális hulladéklerakó infrastruktúrájának tervezése és kiépítése, mely magába foglalta az utak és térburkolatok, közmüvek, vízelvezetés, talajvíz megfigyelö kutak kiépitését, az elektronikus hídmérleg alapozását, kerítés megépítését és a szabad területek parkositását, füvesítést és növénytelepitést.

A Mérnök és a kedvezményezett önkormányzat képviselöi bizonyos mértékig kényszerhelyzetben járultak hozzá a szerződés lezárásához (erre az eljárási szabályok lehetőséget adtak), ugyanis a 2. sz. építési tender szerződése 2004. július 5-én aláirásra került és minél előbb át kellett adni a területet a 2. tender kivitelezöinek.

$\mathrm{Az}$ elmaradó munkák: füvesítés, fásítás, szervizút rekonstrukció, tüzcsapok beépítése, jegyzőkönyvben rögzítésre kerültek, pótlási határidővel. Ezek túlnyomó része időközben már elvégzésre került. A terület parkosítása csak a 2. sz. építési tender befejezése után került sor.

Meg kell emlitenünk, hogy az l-es és 2-es épitési szerződés munkái eredetileg egy közös tenderben szerepeltek. A szétválasztásra a közbeszerzési eljárás gyorsítása érdekében került sor. Ez utóbb jelentős szakmai problémák forrása lett. Részben azért, mert a szétválasztás során a tervezők nem jártak el elég körültekintően és a két új tender nem illeszkedett egymáshoz tökéletesen. Az 1-es építési szerződésben szereplő nyomvonalas létesítmények, csatornák, vezetékek, csövek nyomvonalának tervei, végpontjai helyenként eltértek, vagy nem illeszkedtek a 2. tender dokumentációjában szereplö tervekhez.

Másrészt a határterületek munkáinak elvégzése során mindkét kivitelezöi csoport úgy gondolta, hogy bizonyos munkafázisokat a másik tender keretében kell, vagy kellett volna 
elvégezni. A 2. tender kivitelezői természetesen hátrányba kerültek, mert a viták és konfliktusok ellenére, a Mérnök utasítása alapján végül neki kellett minden hiányosságot felszámolni és pótmunkát elvégezni. Még az 1-es szerződés keretében minőségileg nem megfelelő nyomvonalas létesítmények, csövek cseréjét is.

\section{Eszközbeszerzési tender - Eszközbeszerzési szerzödés $(3 \mathrm{db})$ :}

A tender tárgya volt a következő feladatok ellátásához eszközök beszerzése: Jármúvek: lakossági hulladékok összegyüjtése és elszállítása a regionális hulladéklerakó telepre. Szelektív hulladékgyújtö rendszer bövitése: lakossági hulladékok szelektív gyüjtése és ideiglenes tárolása. Kötörö berendezései: kőtörő berendezés az építőipari hulladékok feldolgozására (beton, tégla, stb.) külső energiaforrástól fuiggetlen módon. Komposztáló berendezései: lebomló hulladékok komposztálása.

A beszerzési tender keretében minden, a projekt megvalósitásához szükséges eszköz, jármü, munkagép, berendezés, konténer beszerzésre került, két évvel a projekt tényleges befejezése elött. A jármüvek, munkagépek rövid idő után üzembe helyezésre kerültek, a többi eszköz tárolásáról a szükséges építési munkák befejezéséig (2-es és 3-as építési tender) gondoskodni kell, kellett. Ez azt jelenti, hogy megfelelö tárolási lehetőség hiányában másfél, két évig álltak, állnak ezek a berendezések a szabad ég alatt a beruházás területén, kitéve az időjárás káros hatásainak. Örzésủkröl folyamatosan gondoskodni kell, és még ennek ellenére is elöfordult szándékos rongálás (komposztforgató gép tükör lefeszítése). A szelektív gyüjtő konténerek fa borításának festése teljesen tönkrement, kihelyezés elött újra kell festeni. Vita folyik arról, hogy ez kinek lesz a feladata, a beszállitó szerint, mivel a rendeltetésszerü használatba vétel nem történ meg, nem garanciális feladat az újrafestés.

\section{IV: 2.sz. Épitési tender - 2.sz. Építési szerzödés:}

A szerződés tárgya a meglévő hulladéklerakó korszerüsítése, melynek során a meglévő depóniatér lezárását és annak tetején az új lerakótér aljzatszigetelését kell megoldani, továbbá ki kel építeni a csurgalékvíz gyüjtő drénhálózatot, a szivárgó résfalat, gázkutakat és a biogáz gyưjtőhálózatot. Feladat továbbá egy szennyviztisztitó telep és egy biogáz-hasznosító mü megépítése, valamint egy komposztáló telep létesítése, a szükséges csarnoképületekkel.

A projekt egésze szempontjából meghatározó jelentőségü, legnagyobb tender nagy nehézségek árán, bonyolult konfliktusok és állandó viták közepette, és többszöri határidő módosítás után 2007. I. félévére befejeződött, de bizonyos szempontból még most sincs vége.

\section{A müszaki átadás-átvételi eljárás:}

Az átadás-átvételi eljárást megelőzően két váratlan esemény is bekővetkezett, egy héttel korábban egy tüzeset, két nappal az átadás-átvétel kitüzött időpontja elött egy özönvízszerüen lehulló csapadék. A tüzeset a depónia folyamatos üzemeltetése során beszállított hulladék esetében következett be, nem tisztázott, hogy öngyulladás vagy szándékos gyújtogatás miatt következett be. A tüzet reggel 7 órakor észlelték, az oltás fél nyolc és nyolc között kezdődött és tíz órára fejeződött be. Földtakarással és vízsugárral - saját földmunkagépekkel és a tüzoltóság segítségével -2 óra alatt sikerült eloltani. (Speciális jellege miatt a jelentősebb depónia-tüzek eloltása hetekig is eltarthat.) Sajnos a már elkészült szigetelés több helyen megsérült, de ennek kijavítása csak néhány napot vett igénybe, a müszaki átadás-átvételt nem hátráltatja. 
A nagyobb problémát, a majus 4-én és 6-án lehullott nagy mennyiségü csapadék okozta. A depónia 3. sz. kazettájának frissen elkészült laza földtakarása több száz négyzetméteren megcsúszott, a terhelésétől megszabadult HDPE szigetelő fólia alatt képződő biogáz kis tủlnyomása ellenére a megcsúszott rézsủ terulletén a fóliát felfújta és további takaró földet túrt le magáról. A 2006. május 8-ára kitủzött mủszaki átadás-átvételi eljárás azzal kezdődött, hogy a Mérnök, a kedvezményezett önkormányzat projekt menedzsere, a kivitelezö konzorcium képviselöi és a tervezők azt vizsgálták, meghiusíthatja-e az eljárást a kialakult helyzet. A tervezők szerint a fólia felpúposodása egyedi eset, megfelelő műszaki megoldást 1-2 napon belül kidolgozzák. A túlnyomás 24 órán belül megszüntetető és a rézsü földtakarásának helyreállítását haladéktalanul megkezdik. Ez azt jelenti, hogy az első látásra rendkj́vül súlyosnak tünő müszaki problémát viszonylag rövid időn belül el fogják háritani és ez nem akadályozza a müszaki átadás-átvétel lefolytatását.

A műszaki átadás-átvétel megtörtént, az üzemeltető a létesítményeket üzemeltetésre átvette, de az átadás-átvétel pillanatában regisztrált és fennálló müszaki hiányosságok tekintetében kikötötték azok szoros határidővel törtẻnő elhárítását, továbbá rögzitették a garanciális idöszak megkezdésének határozatlan idejü - a hiányosságok maradẻktalan felszámolásảnak időpontjáig történő - elhalasztását. Ez természetesen a (jó) teljesítési garancia lehívhatóságának határidejére is vonatkozott.

\section{A 2. sz épitési tender különbözö létesítményeinek ãzemeltetési tapasztalatai:}

A depónia és kiegészitő létesitményei esetében a kedvezményezett és mérnöki szervezet képviselői is, már a megvalósítás szakaszában jelezte, hogy bizonyos müszaki megoldások várhatóan nem fogják biztosítani a megfelelő müködést és az üzemeltetés biztonságát. Sajnos az üzemeltetési tapasztalatok ezeket az aggályokat legtöbb esetben beigazolták. A legtöbb és leglátványosabb problémát a biogáz gyưjtỏ és hasznosító rendszer nem megfelelő tervezése, méretezése okozta. A támasztó töltések hiánya miatt hulladékból kialakított és a depónia felület egészéhez hasonlóan szigetelt 1: 3 arányú részü külső oldalán folyamatosan termelödö és a korona szinten felhalmozódó biogáz a depó különböző pontjain ismétlődően megjelenő felpúposodást okozott. Többszöri, csak lokális eredményt hozó beavatkozást követően sikerült elérni 2008. augusztus végén (több mint egy évvel a hivatalos müszaki átadás-átvételi eljárás után), hogy a depóniát határoló külsö rézsük koronaszintjén végigvezetett csővezeték utólagos kiépitésével a folyamatosan képződő biogáz a szigetelö fólia alól, megfelelő csatlakozó szerelvények segítségével elvezethető és így a felpúposodás megszüntethető. A korábban az elsỏsorban a felpúposodás miatt megcsúszott rézsűket helyreállították és vastagabb takaróréteg kialakításával megerősítették. A további megcsúszások elkerülése érdelében a külső takaró fólia felületére bordázatot erősítettek. Ha a felpúposodás jelensége nem ismétlödik, akkor ez a müszaki megoldás biztosítja, hogy további rézsủ csúszások ne forduljanak elö.

A biogáz-hasznosítás megtervezésekor a gázmotorok teljesitményét alul méretezték és nem tervezték be a hasznosítás tényleges megvalósitását biztosító elektromos csatlakozásokat. Elmaradt továbbá a kondenzvíz leválasztó kialakítása, így az elszivó rendszerben a biogázból kicsapódó vízpára közvetlenül veszélyezteti a kompresszorok és a gázmotor üzembiztosságát. Ez utóbbi probléma jelentős konfliktusok és hosszas viták eredményeként 2008. szeptemberében még a hidegebb időjárás beköszöntése előtt megoldódott. A másik, két jelentősebb probléma esetében a kivitelezők a tender kiírás pontatlanságára hivatkozva elzárkóztak a további együttmüködéstől. Az üzemeltető érdekei, viszont már rövidtávon is azt 
követelik, hogy a megfelelő müszaki megoldást mielöbb megtalálja. Tárgyalásokat folytat lehetséges partnerekkel a villamos energia kapacitás megduplázása érdekében. Továbbá a jelenleg rendelkezésre álló villamos energia telephelyen belül történö hasznosítására müszaki megoldást kerestek. Jól jellemzi a kivitelezők hozzáállását, hogy a másfélévvel korábban már felmerült javaslatra akkor hivatalosan azt nyilatkozták, hogy müszakilag nem megoldható. Időközben kiderült, hogy a komposztáló üzem elszívó rendszerének müködtetéséhez szükséges villamos energiát, viszonylag egyszerü módon, mindössze a megfelelö vezeték kiépítésével a biogáz-hasznosító egység biztositani tudja. Az, hogy ennek megvalósítására eddig nem került sor az üzemeltetőnek közel 10 millió Ft kárt okozott. Az üzemeltető vállalta, hogy saját költségére kiépíti a szükséges vezetékszakaszt, de ehhez a kivitelező nem járult hozzá. Közölte, hogy amennyiben erre sor kerül nem vállalja a kötelező garanciát az érintett létesítmények esetében. Az üzemeltető válaszul kilátásba helyezte a vezeték kiépítésének és az elmaradt haszonnak peres úton történő utólagos behajtását.

A komposztáló üzem esetében, már a kiviteli tervek jóváhagyása során felmerült, hogy a hasonló technológiák esetében szokásos külsỏ környezetböl elszívott levegỏ felmelegítésére szolgáló hőcserélő nincs betervezve. A szokásos müszaki megoldás a szellőztető rendszeren keresztül kibocsátott meleg levegővel közös hőcserélőn keresztül előmelegíteni a beszívott friss levegőt. A kivitelezők állították, hogy ez teljes egészében szükségtelen és a technológia müködőképességét nem befolyásolja. Az átadást követő melegebb hónapokban valóban nem jelentkezett ezzel kapcsolatos probléma, azonban, amikor a téli hónapokban a külső hömérséklet $5-10^{\circ} \mathrm{C}$ fok alá csökkent, a komposztáló bokszokban elhelyezett nyersanyagot az átszívott hideg levegő oly mértékben lehütötte, hogy az egyébként exoterm lebomlási folyamat (amely egyébként $50-60{ }^{\circ} \mathrm{C}$ fokra melegíti fel az anyagot) teljesen leállt. A kivitelezök azt állitották, hogy a nyersanyag nem megfelelö összetételü, kevés nagy nedvességtartalmú gyorsan lebomló anyagot tartalmaz. $\mathrm{Az}$ üzemeltető állítása szerint pontosan a kivitelezők által megadott összetétel szerint állították be a különböző alapanyagok arányát. Az elhúzódó vita a jó idő beálltával okafogyottá vált, de az utolsó 2008 . augusztusi egyeztetésen az üzemeltetö jelezte, hogy ez a kérdés továbbra is napirenden van, kérte a hideg idő beálltát követően a probléma közös helyszíni vizsgálatát.

Feltehetően a betonozás során elkövetett mulasztás miatt a D-i komposztáló sor bokszainak fenékszintjén folyamatos szivárgás volt tapasztalható. Ennek elhárítására a kivitelező 2008. nyarán kísérletet tett, de a mérnöki szervezet szerint ez nem elegendő, felszólították a kivitelezőt, hogy végleges műszaki megoldást dolgozzon ki a probléma megoldására.

\section{V: A 3. sz. Építési tender (rekultiváció, hulladékudvarok és hulladékgyüjtő szigetek):}

A tender az eredeti elképzelések szerint alábbi feladatokat tartalmazta:

- települési hulladéklerakók rekultiválása $(27 \mathrm{db})$

- hulladékudvarok építése a településeken és Szegeden $(29 \mathrm{db})$

- hulladékgyüjtőszigetek kialakítása $(72 \mathrm{db})$

A Magyar Kormány és az Európai Unió között időközben megállapodás született, hogy a hazai ISPA projektek jelentősen megnövekedett rekultivációs költségei miatt a rekultivációs feladatokat külön program keretében a 2008-2013 között fogják megvalósítani.

Tekintettel arra, hogy a 3. sz. Építési tender a rekultivációs feladatok mellett a hulladékudvarok és hulladékgyüjtő szigetek kiépítését is tartalmazta (az ezekheż szükséges 
eszkőzök, konténerek az eszközbeszerzés keretében már két éve megérkeztek), javasolták a tender megbontását. Az új 3. sz. tender tartalmazta a hulladékudvarok és hulladékgyủjtő szigetek kiépítését, mig a rekultivációs feladatok külön projektben kerülnek megvalósításra, késöbb meghatározott befejezési határidővel.

A többletköltségek miatt így a 3. sz. Építési tender megbontásra került az alábbiak szerint:

1. a hulladékudvarok és hulladékgyũjtő szigetek kilakítása (3.sz. Építési tender)

2. a lerakók rekultivációja (4. sz. Építési tender)

\section{3.sz. Építési tender - 3.sz. Épitési szerzốdés:}

A szerződés tárgya volt az akkor már meglévő szelektív hulladékgyüjtő hálózat kibővítése, 29 $\mathrm{db}$ új hulladékudvar megépítésével, valamint $72 \mathrm{db}$ hulladékgyüjtő szigetek kialakításával, Szegeden és a környező kisebb településeken.

10-11. A szegedi hulladékgyưịtő szigetek műszaki átadás-átvételi eljárása 2008. áprilisában zajlott le. Az, azóta eltelt üzemeltetési időszakban az alábbi hiányosságok és müködési zavarok jelentkeztek.

A térburkolatoknál a dilatációs hézagok nem időben lettek kialakítva, emiatt a térburkolatok számos helyen megrepedtek. Az épületek egyenlőtlen süllyedéséből adódóan falaknál, áthidalásoknál, falaknál repedések keletkeztek. A tetőszerkezet természetes mozgásából adódóan belső födémkialakítások elmozdultak, nyílászárók illesztésénél hibák léptek fel, a nyílászárók $80 \%$-nál elmozdulások tapasztalhatóak. A beépített nyílászárók, elsősorban ajtók minősége nem megfelelö, az ajtótoknál repedések láthatóak, számos esetben az ajtótáblák kiszakadtak a helyükből. A garanciảlis bejelentéseket a mérnöki szervezet felé megtörtént, és ezzel egy időben egy igazságügyi szakértői vélemény elkészítését is megrendelte az üzemeltető.

VI: 4. sz. Építési tender - Új KEOP pályázat (kistelepülési környezetszennyező lerakó telepek rekultivációja)

Az eredeti 3. sz. Épitési tenderből kikerült rekultivációs feladatok a támogatási szerződés módosítása után hivatalosan is kikerültek a projektből. Jogi szempontból teljesen új eljárás keretében, de változatlan múszaki tartalommal, mint önálló projektet, a Kormány által 2008ban meghirdetett Környezet és Energia Operatív Program (KEOP) fogadta be a rekultivációs programot. Megvalósulás híján egyelöre üzemeltetési tapasztalatokról nem beszélhetünk.

\section{Az üzemeltetési zavarok okainak feltárása:}

A projekt megvalósítása során beszerzett eszközök és megvalósított létesítmények üzemeltetési tapasztalatainak értékelése során nyilvánvalóvá vált, hogy az egyes tenderek megvalósítása során tapasztalt müködési zavarok és a későbbi üzemeltetés során jelentkezö problémák között egyértelmủen ok-okozati összefüggés van.

A problémák egyik kiinduló pontja az erős piaci verseny, árverseny, amely erősen alulkalkulált ajánlatok megszületését eredményezi (versenyár szemlélet), amelyek sok esetben nem fedezik a tender kírás szerinti mủszaki tartalom megfelelö minőségben történö megvalósítását. A,jól pályázó" cégek versenyképes (erősen alulkalkulált) árajánlataikkal 
több jelentős tenderben is sikeresek lehetnek. Ez újabb problémák forrása, hiszen saját termelési, építési kapacitásaik nem elegendőek, legfeljebb csak egy nagyobb tender megvalósítására.

Ha a tervezett költségek nem fedezik kívánt müszaki tartalom megvalósítását, de a szerződést már aláírták, a kárenyhítés a müszaki tartalom csökkentésével, olcsóbb megoldások alkalmazásával, az eredeti kiírástól történö eltérések segítségével valósulhat meg. Az így csökkentett költségektöl remélik kivitelezők, hogy a nyilvánvaló veszteség helyett esetleg valami nyereséget produkálnak. Ha a tender kiírás nem megfelelö színvonalú, vagy pontatlan, esetleg félreérthető, vagy félremagyarázható, akkor ez a taktika gyakran eredményes. Mindenesetre a kivitelezỏ ilyen irányú kísérletei folyamatosak és állandó konfliktusokat eredményeznek a Mérnöki szervezettel és a kedvezményezett képviselöivel.

A költségcsökkentés olcsó, helyi alvállalkozók alkalmazásával is megvalósítható, akik ugyanazt a munkát gyakran jóval olcsóbban elvállalják. A hazai gyakorlatban jellemző a többszintü, külsö szemlélö számára teljesen áttekinthetetlen alvállalkozói kapcsolatrendszer. Sok a kétes szakmai felkészültségü ám, de nagyon olcsó alvállalkozó.

Szakmai felkészületlenség, hozzá nem értés sajnos nem csak az alvállalkozók esetén merül fel. Elsősorban a kapacitáshiány miatt nem jut elegendő, megfelelően képzett szakember mindenhova. Sokszor kényszerböl neveznek ki fiatal, elegendő szakmai tapasztalattal nem rendelkező vezetőket az egyes projektek élére. Ennek eredménye szervezetlenség, alacsony hatékonyság, rossz minőségü munka, hibás teljesítés, ami további konfliktusok forrása. Tovább növeli a kockázatokat az is, hogy a konzorciumi tagok menedzsmentje is gyakran változott, változik.

Legtöbbször konzorciumok pályáznak, amelyeken belül a viszonyok nem.rendezettek a sem a pályázat elökészítése során, sem a sikeres pályáztatás utáni első hónapokban. Az összhang hiánya miatt, valamint a pénzelosztással kapcsolatos viták következtében a kivitelező konzorciumok müködését folyamatosan végigkísérik a belő viták, konfliktusok. Az első időszakban a legtöbb vizsgált tender esetében nincs valódi projekt szervezet és megfelelő irányitás, az egyes konzorciumi tagok képviselőinek párhuzamos hatáskörei döntési zavarokat eredményeznek, a feladat és hatáskörök zavarosak és áttekinthetetlenek, az egyéni felelösségvállalás teljesen elsikkad.

A konfliktusok következtében és esetlegesen, ha veszteséges a tender, a projekt irányítása jelentősen átalakul. Válságmenedzselés keretében a kárenyhítés, a veszteségek csökkentése érdekében a legnagyobb konzorciumi tag veszi át az irányítást, végre megalakul egy hatékony projekt szervezet, amelyben a kisebb konzorciumi tagok alárendelt szerepet kapnak.

Gyakran fordul elö, hogy a feladatok és hatáskörök szigorú elhatárolásával a tendert formálisan több kisebb tenderre darabolják szét. A felosztás eredményeként létrejött, kisebb munkarészeket az egyes konzorciumi tagok önállóan, saját hatáskörben és irányítással, a többi feladattól függetlenül kísérlik meg végrehajtani. Az egyes elkülönített, de szakmailag egymással összefüggö munkarészeknẻl viták ẻs konfliktusok forrása, hogy a határterületek esetében pontosan kinek, mit és milyen határidőre kell végrehajtani. 


\section{3. ŌSSZEGZÉS, KÖVETKEZTETÉSEK}

A hazai európai uniós támogatással megvalósuló környezetvédelmi infrastruktúra fejlesztési projektek lebonyolítási és üzemeltetési tapasztalatai jelentős segítséget jelenthetnek a további, strukturális alapokból finanszírozott projektek megvalósítása során. A tervezés, elökészítés, a közbeszerzési eljárás, valamint az egyes tenderek megvalósulási tapasztalatainak vizsgálatát követően a „Szeged Regionális Hulladékgazdálkodási Programja” elnevezésű ISPA/Kohéziós Alap projekt kertében beszerzett eszközök, megvalósult létesítmények üzemeltetési tapasztalatait vizsgáltam a projektmenedzsment tudomány szemszögéböl. A közbeszerzési terv alapján végrehajtott közbeszerzési eljárás egyes tenderei esetében kevésbé, míg más tenderek esetében rendkívül súlyos anomáliák, müködési zavarok, üzemeltetési problémák jelentkeztek.

A legsúlyosabb megállapitás, hogy a létesítménymegvalósítás területén, az építési tenderek szerződéseinek teljesitése során, szisztematikusan ismétlődve tapasztalhatók ugyanazok a tervezési, szervezési, kivitelezési, minőségi problémák, müködési zavarok, határidőcsúszások, melyek egyértelmü okai a késöbbi üzemeltetési problémáknak is. (Valamint folyamatos forrásai voltak a kivitelezők, a mérnöki szervezet, közremúködő szervezet és a kedvezményezettek közötti konfliktusoknak.)

Ezek hátterének vizsgálata egyértelmủen bizonyítja, hogy az egyes tenderek megvalósítása során tapasztalt problémák közvetlen ok-okozati összefüggésben vannak az üzemeltetés során tapasztalt müködési zavarokkal. Ennek elsödleges okai a kivitelezök esetében tapasztalható szakmai felkészületlenség, kapacitás hiány, a szervezetlenség, valamint az együttmüködő partnerek közötti összhang hánya. A nem megfelelö müszaki tartalmú kivitelezés mellett súlyos problémákat okozott az alacsony szakmai szinvonalú tervezés, melynek egyik oka a szakmai hozzá nem értés, a másik a költségcsökkentés érdekében végrehajtott tudatos „alultervezés."

\section{FELHASZNÁLT IRODALOM}

Görög MIHÁLY (2001): Bevezetés a projektmenedzsmentbe, Aula Kiadó, Budapest. A „Szeged Regionális Hulladékgazdálkodási Programja” dokumentumai 